\title{
EFEK HIPOLIPIDEMIK EKSTRAK ETANOL LIDAH BUAYA (Aloe vera L) PADA TIKUS PUTIH JANTAN MODEL HIPERKOLESTEROLEMIA
}

\author{
HYPOLIPIDEMIC EFFECT OF ALOE VEGETABLES (Aloe vera L) EXTRACT ON \\ HYPERCHOLESTEROLEMIC MODELLING WISTAR MALE RATS
}

\author{
Devi Usdiana Rosyidah, Yustika Qasthari Primayanti, Oktein Satriyani \\ Fakultas Kedokteran Universitas Muhammadiyah Surakarta \\ Korespondensi; dr. Devi Usdiana R., M. Sc. Email: dur203@ums.ac.id
}

\begin{abstract}
ABSTRAK
Hiperlipidemia merupakan bagian dari permasalahan kesehatan nasional terkait penyakit kardiovaskuler. Meningkatnya animo masyarakat untuk menggunakan bahan alam sebagai tata laksana hiperlipidemia menginspirasi penelitian untuk mengetahui manfaat ekstrak lidah buaya. Ekstrak lidah buaya (Aloe vera L.) mengandung zat aktif acemannan (glukomanan) dan selulosa yang dapat menurunkan profil lipid. Penelitian ini bertujuan untuk mengetahui efek ekstrak etanol lidah buaya terhadap profil lipid tikus jantan model hiperkolesterolemia. Desain penelitian menggunakan eksperimental laboratorium dengan metode pre and post test with control group design. Penelitian melibatkan 25 ekor Rattus norvegicus putih jantan yang diinduksi pakan tinggi lemak selama 14 hari. Subjek dibagi 5 kelompok yaitu : kontrol negatif (aquades), kontrol positif (kolestiramin 0,2g/200gBB/hari), ektrak etanol Aloe vera L dosis I (0,3g/200gBB/hari), ektrak etanol Aloe vera L dosis II (0,6g/200gBB/hari), ektrak etanol Aloe vera L dosis III (1,2g/200gBB/hari). Pengukuran kadar profil lipid dilakukan pada hari ke-7, hari ke-21, dan hari ke-35. Hasil uji Shapiro-Wilk dan Lavene test didapatkan hasil semua kelompok datanya normal dan homogen. Hasil Paired T-Test didapatkan nilai p=0,000 baik untuk trigliserid, LDL kolesterol, maupun kolesterol total. Selanjutnya uji parametrik One Way Anova hasil p<0,05 untuk ketiga profil lipid. Uji LSD terhadap kadar trigliserid kelompok aquades dengan ekstrak etanol $70 \%$ Aloe vera $L$ dosis 0,3g/200gBB/hari, 0,6g/200gBB/hari, dan 1,2g/200gBB/hari berturut-turut $p=0,012, p=0,000$ dan $p=0,000$. Uji LSD terhadap LDL kolesterol dan kolesterol total kelompok aquades dengan ekstrak etanol $70 \%$ Aloe vera L hanya pada dosis 1,2g/200gBB/hari yang berbeda signifikan dengan nilai p=0,006 dan p=0,001. Ekstrak etanol $70 \%$ Aloe vera L dosis 1,2g/200gBB/hari dapat menurunkan profil lipid berupa kadar trigliserid, LDL kolesterol dan kolesterol total dari tikus putih jantan model hiperkolesterolemia.
\end{abstract}

Kata kunci: Aloe Vera L, Profil Lipid, Glukomanan

\begin{abstract}
Hyperlipidemia was a national health problem related to cardiovascular disease. The increasing public interest in natural materials as a management of hyperlipidemia research with natural ingredients. Aloe vera $L$. extract contained acemannan (glucomannan) and cellulose which could reduce lipid profiles. This aim of this study was to determine the effect of Aloe vera extract on the lipid profile of hypercholesterolemic modelling wistar male rats. This study used a laboratory experimental research design. The method was pre and post test with control group design. This study used 25 male Rattus norvegicus induced by high-fat feed for 14 days. Subjects were divided into 5 groups: negative control group (aquadest), positive control group (cholestiramine $0.2 \mathrm{mg} / 200 \mathrm{gBB} /$ day), extract of Aloe vera $L$ dose $0.3 \mathrm{~g} / 200 \mathrm{gBB} /$ day, extract of Aloe vera $L$ dose $0.6 \mathrm{~g} / 200 \mathrm{gBB} / \mathrm{day}$, extract of Aloe vera $L$ dose $1.2 \mathrm{~g} / 200 \mathrm{gBB} /$ day. Measurement of lipid profile levels was carried out on the $7^{\text {th }}$ day, $21^{\text {st }}$ day, and $35^{\text {th }}$ day. Shapiro-Wilk test and Lavene test showed all data were normal and homogenous. The Paired $t$-Test results obtained $p=0,000$. One Way Anova test with triglyceride showed $p<0,05$. The LSD test showed for the aquadest group triglyceride levels with $70 \%$ ethanol extract Aloe vera L dose $0.3 \mathrm{~g} / 200 \mathrm{gBB} / \mathrm{day}$, $0.6 \mathrm{~g} / 200 \mathrm{gBB} /$ day, and $1.2 \mathrm{~g} / 200 \mathrm{gBB} /$ day were $p=0.012, p=0,000$ and $p=0,000$ respectively. Least significance different test for LDL cholesterol and total cholesterol in the aquadest group with $70 \%$ ethanol extract of Aloe vera $L$ only at a dose of $1.2 \mathrm{~g} / 200 \mathrm{gBB} /$ day were significantly different with a value of $p=0.006$ and $p=0.001$. The conclusion was ethanol extract $70 \%$ Aloe vera L dose $1.2 \mathrm{~g} / 200 \mathrm{gBB} /$ day could reduce lipid profile such as triglyceride levels, LDL cholesterol and total cholesterol in hypercholesterolemic modelling wistar male rats.
\end{abstract}

Keywords: Aloe Vera L., Lipid Profile, Glucomannan

How To Cite: Rosyidah, D., Primayanti, Y., \& Satriyani, O. (2019). EFEK HIPOLIPIDEMIK EKSTRAK ETANOL LIDAH BUAYA (Aloe vera L) PADA TIKUS PUTIH JANTAN MODEL HIPERKOLESTEROLEMIA. Biomedia, 11(1), 41-47. doi:https://doi.org/10.23917/biomedika.v11i1.7662

DOI: https://doi.org/10.23917/biomedika.v11i1.7662 


\section{PENDAHULUAN}

Hiperlipidemia adalah kondisi yang dikarakteristikkan dengan peningkatan satu atau lebih lipid dalam darah. Lipid ini termasuk trigliserid, kolesterol, ester kolesterol, fosfolipid, dan lipoprotein. Lipoprotein terdiri dari very low-density lipoprotein (VLDL) dan low-density lipoprotein (LDL) yang meninggi diikuti penurunan high-density lipoprotein (HDL) (Shattat, 2014). Peningkatan kadar lipid dalam darah merupakan faktor risiko terjadinya penyakit kardiovaskuler (Nelson, 2013). Penyakit kardiovaskuler merupakan penyebab morbiditas dan mortalitas didunia (Dariush, et al., 2015; Murray, et al., 2012).

World Health Organization (WHO) tahun 2012 dalam datanya menunjukkan kematian akibat penyakit kardiovaskuler $31 \%$ (17,5 juta dari 56,5 juta orang meninggal) di seluruh dunia dan lebih dari $3 / 4$ kematian tersebut terjadi di negara berkembang dengan tingkat penghasilan rendah sampai sedang (Kemenkes RI, 2017). Hasil penelitian sporadis di 15 Kabupaten/ Kota di Indonesia, oleh Badan penelitian dan pengembangan kesehatan kementrian kesehatan RI, memberikan fenomena 17,7\% kematian disebabkan oleh Stroke dan 10,0\% kematian akibat Ischaemic Heart Disease (Budijanto, 2015). Data Riskerdas tahun 2018 menunjukkan penderita penyakit jantung dan stroke di jawa tengah sebesar 1,6\% dan 11,8\%. Dengan karakteristik subjek, mulai usia 15 tahun sampai dengan lebih dari 75 tahun, menunjukkan prosentase penderita semakin meningkat seiring bertambahnya usia. Penderita penyakit jantung dari jenis kelamin, laki-laki dan perempuan memiliki prosentase hampir setara. Prosentase penderita yang tinggi cenderung didapat pada masyarakat yang tidak bekerja, atau pekerja kantoran dan tinggal diperkotaan. Sedangkan penderita stroke memiliki karakteristik cenderung pada laki-laki, tingkat pendidikan rendah, tidak bekerja, dan tingggal diperkotaan (Kemenkes RI, 2018).

Wadhera et al., (2016) menjelaskan penurunan kolesterol total dapat menurunkan kematian akibat coronary heart disease (CHD) sebesar 19-46\%. Low-density lipoprotein cholesterol (LDL-C) sekarang juga menjadi target untuk dilakukan terapi terhadap hiperlipidemia. Sedangkan hipertrigliserid meningkatkan risiko terbentuknya aterosklerosis pada penyakit kardiovaskuler (Watts et al., 2013; Nordestgaard, 2016).
Aloe vera $L$ merupakan tanaman yang banyak dimanfaatkan untuk berbagai produk nutrisi, produk farmasi dan kosmetik (Chandegara and Varshney, 2013; Miroddi et al., 2015). Pada produk farmasi Aloe vera L memiliki efektivitas farmakologi antara lain : antitumor, anti ulkus, antiviral, ansiolotik, hipolipidemik, hipoglikemik, anti aterogenik, anti fungal, antioksidan, anti bakterial, nefroprotektif dan membantu penyembuhan luka (Chatterjee $e t$ al., 2013; Kar and Bera, 2018). Zat aktif biologi yang terkandung dalam Aloe vera $L$ lebih dari 100 macam. Tanaman ini kaya dengan anthraquinones/anthrones, vitamin, asam amino, sterol tanaman (campestrol, cholesterol, $\beta$ sitosterol) dan polisakarida. Polisakarida yang terdapat dalam Aloe vera $L$ termasuk B1-3 dan B1-4 Glucomannan (Chatterjee et al., 2013). Glukomanan merupakan suatu polisakarida jenis hemiselulosa. Glukomanan terdiri dari ikatan rantai glukosa, mannose, dan galaktosa. Secara alami komponen ini ada pada tanaman. Komponen ini tidak dapat dicerna secara enzimatik. Glukomanan sangat efektif dalam menyerap asam empedu. Asam empedu sendiri berfungsi mengemulsi lemak. Dengan demikian lemak yang telah teremulsi akan dibawa keluar bersama feces, akibatnya kolesterol yang diikat oleh serat glukomanan tersebut tidak masuk ke pembuluh darah (Wirya, 2012).

Penelitian eksplorasi efek ekstrak etanol lidah buaya terhadap profil lipid tikus jantan model hiperkolesterolemia masih sangat terbatas

\section{METODE PENELITIAN}

Penelitian ini menggunakan desain eksperimental laboratorium. Metode penelitian menggunakan pre test and post test with controlled group design. Subjek penelitian adalah tikus putih jantan (Rattus norvegicus), berat badan \pm 200 gram, dan berumur 1-2 bulan. Induksi hiperkolesterolemia menggunakan metode pakan tinggi lemak. Pakan ini mengandung kolesterol lemak kambing $10 \%$, kuning telur ayam $1,5 \%$, dan minyak kelapa $1 \%$ (Hardiningsih \& Nurhidayat, 2006). Pembagian hewan uji menjadi 5 kelompok yaitu kontrol negatif diberi aquades, kontrol positif diberi kolestiramin $0,2 \mathrm{mg} / 200 \mathrm{gBB}$, perlakuan ekstrak lidah buaya dosis I $0,3 \mathrm{~g} / 20 \mathrm{gBB} /$ hari, perlakuan ekstrak lidah buaya dosis II $0,6 \mathrm{~g} / 200 \mathrm{gBB} / \mathrm{hari}$, perlakuan ekstrak lidah buaya dosis III $1,2 \mathrm{~g} / 200 \mathrm{gBB} / \mathrm{hari}$. Profil lipid yang di cek adalah kadar trigliserid, LDL dan kolesterol total. Uji statistik yang dipakai yaitu Shapiro-Wilk, Levene 
Test, Paired T-test, Uji one way ANOVA dan uji Least Significance Difference (LSD).

\section{HASIL DAN PEMBAHASAN}

Tanaman lidah buaya (Aloe vera L.) yang digunakan pada penelitian ini adalah Aloe vera
(L.) Burm. F. hasil determinasi sesuai surat dari Laboratorium program studi Biologi Fakultas Matematika dan Ilmu Pengetahuan Alam Universitas Negeri Sebelas Maret Surakarta no. 238/ UN27.9.6.4/ Lab/2017.

Tabel 1 : Kadar Trigliserid, LDL-Kolesterol Dan Kolesterol Total (dalam mg/dL \pm Standar Deviasi)

\begin{tabular}{|c|c|c|c|c|}
\hline Profil lipid & Kelompok perlakuan & Sebelum induksi & Setelah induksi & $\begin{array}{c}\text { Setelah } \\
\text { perlakuan }\end{array}$ \\
\hline \multirow{5}{*}{ Trigliserid } & Kolestiramin & $63,12 \pm 9,8$ & $81,14 \pm 40,3$ & $40,35 \pm 21,3$ \\
\hline & Aquades & $67,45 \pm 12,1$ & $86,70 \pm 43,5$ & $68,81 \pm 53,8$ \\
\hline & ekstrak Aloe vera L $(0,3 \mathrm{~g} / 20 \mathrm{gBB} / \mathrm{hari})$ & $62,44 \pm 7,7$ & $102,64 \pm 13,2$ & $80,59 \pm 13,2$ \\
\hline & ekstrak Aloe vera L $(0,6 \mathrm{~g} / 20 \mathrm{gBB} / \mathrm{hari})$ & $57,05 \pm 8,6$ & $101,27 \pm 18,6$ & $54,72 \pm 27,8$ \\
\hline & ekstrak Aloe vera L $(1,2 \mathrm{~g} / 20 \mathrm{gBB} /$ hari $)$ & $62,48 \pm 6,9$ & $89,33 \pm 44,9$ & $55,55 \pm 28,0$ \\
\hline \multirow{5}{*}{ LDL-Kolesterol } & Kolestiramin & $35,51 \pm 8,0$ & $53,33 \pm 26,8$ & $14,23 \pm 9,3$ \\
\hline & Aquades & $38,55 \pm 8,0$ & $52,29 \pm 26,5$ & $52,04 \pm 27,0$ \\
\hline & ekstrak Aloe vera L $(0,3 \mathrm{~g} / 20 \mathrm{gBB} / \mathrm{hari})$ & $38,11 \pm 8,9$ & $65,90 \pm 8,4$ & $46,92 \pm 7,4$ \\
\hline & ekstrak Aloe vera L $(0,6 \mathrm{~g} / 20 \mathrm{gBB} / \mathrm{hari})$ & $44,34 \pm 7,5$ & $69,69 \pm 6,2$ & $32,98 \pm 16,8$ \\
\hline & ekstrak Aloe vera L $(1,2 \mathrm{~g} / 20 \mathrm{gBB} / \mathrm{hari})$ & $40,94 \pm 5,3$ & $56,67 \pm 28,6$ & $23,50 \pm 14,8$ \\
\hline \multirow{5}{*}{ Kolesterol total } & Kolestiramin & $59,36 \pm 8,7$ & $92,96 \pm 5,5$ & $60,65 \pm 7,4$ \\
\hline & Aquades & $60,16 \pm 8,3$ & $90,23 \pm 7,8$ & $88,30 \pm 6,8$ \\
\hline & ekstrak Aloe vera L $(0,3 \mathrm{~g} / 20 \mathrm{gBB} /$ hari $)$ & $59,89 \pm 10,5$ & $93,21 \pm 9,1$ & $79,55 \pm 8,6$ \\
\hline & ekstrak Aloe vera L $(0,6 \mathrm{~g} / 20 \mathrm{gBB} / \mathrm{hari})$ & $69,60 \pm 8,5$ & $100,43 \pm 6,5$ & $79,37 \pm 6,1$ \\
\hline & ekstrak Aloe vera L $(1,2 \mathrm{~g} / 20 \mathrm{gBB} / \mathrm{hari})$ & $64,28 \pm 7,5$ & $98,79 \pm 7,2$ & $69,51 \pm 10,3$ \\
\hline
\end{tabular}

Keterangan : hasil uji Levene test, didapatkan nilai $\mathrm{p}>0,05$ artinya data homogen dan uji Shapiro-Wilk nilai $\mathrm{p}>$ 0,05 artinya data normal. Sedangkan uji Paired T-test data sebelum induksi dan sesudah induksi untuk ketiga profil lipid didapatkan nilai $\mathrm{p}=0,000(\mathrm{p}<0,05)$.

Tabel 2 : Nilai Signifikansi (P) Uji Post Hoc Least Significance Different (LSD) Terhadap Kadar Trigliserida, LDL Kolesterol Dan Kolesterol Total Setelah Perlakuan.

\begin{tabular}{|c|c|c|c|}
\hline \multirow{2}{*}{ Kelompok perlakuan } & \multicolumn{3}{|c|}{ Nilai p } \\
\hline & Trigliserid & LDL kolesterol & Kolesterol total \\
\hline Aquades - Kolestiramin & $0,000^{*}$ & $0,001 *$ & $0,000^{*}$ \\
\hline Aquades - ekstrak Aloe vera $L(0,3 \mathrm{~g})$ & $0,012 *$ & 0,598 & 0,088 \\
\hline Aquades - ekstrak Aloe vera $L(0,6 \mathrm{~g})$ & $0,000 *$ & 0,058 & 0,095 \\
\hline Aquades - ekstrak Aloe vera $L(1,2 \mathrm{~g})$ & $0,000 *$ & $0,006^{*}$ & $0,001 *$ \\
\hline Kolestiramin - ekstrak Aloe vera $L(0,3 \mathrm{~g})$ & $0,000 *$ & $0,002 *$ & $0,001 *$ \\
\hline Kolestiramin - ekstrak Aloe vera L $(0,6 \mathrm{~g})$ & $0,002 *$ & 0,062 & $0,001 *$ \\
\hline Kolestiramin - ekstrak Aloe vera L $(1,2 \mathrm{~g})$ & $0,002 *$ & 0,343 & 0,097 \\
\hline ekstrak aloe vera $\mathrm{L}(0,3 \mathrm{~g})$ - ekstrak Aloe vera $L(0,6 \mathrm{~g})$ & $0,030 *$ & 0,158 & 0,972 \\
\hline ekstrak aloe vera $\mathrm{L}(0,3 \mathrm{~g})$ - ekstrak Aloe vera $L(1,2 \mathrm{~g})$ & $0,044 *$ & $0,022 *$ & 0,052 \\
\hline ekstrak aloe vera $\mathrm{L}(0,6 \mathrm{~g})$ - ekstrak Aloe vera $L(1,2 \mathrm{~g})$ & 0,856 & 0,332 & 0,067 \\
\hline
\end{tabular}

Keterangan : hasil uji One Way Anova didapatkan nilai p < 0,05 untuk ketiga parameter profil lipid diatas. Kemudian dilanjutkan dengan uji LSD didapatkan nilai $\mathrm{p}$ sebagaimana tabel 2. *) nilai $\mathrm{p}<0,05$ artinya berbeda signifikan

Tabel 3 : Korelasi Antar Variabel Dengan Uji Korelasi Pearson

\begin{tabular}{lcccc}
\hline \multicolumn{1}{c}{ Kelompok } & $\begin{array}{c}\text { Nilai signifikansi } \\
(\boldsymbol{p})\end{array}$ & $\begin{array}{c}\text { Koefisien } \\
\text { Pearson }(\mathbf{r})\end{array}$ & $\begin{array}{c}\text { Arah } \\
\text { korelasi }\end{array}$ & Kekuatan korelasi \\
\hline Trigliserid - LDL-kolesterol & 0,000 & 0,760 & Positif & Cukup \\
Trigliserid - Kolesterol total & 0,000 & 0,652 & Positif & Cukup \\
LDL-kolesterol - kolesterol total & 0,000 & 0,947 & Positif & Tinggi \\
\hline Ket
\end{tabular}

Keterangan : hasil uji korelasi baik trigliserid, LDL-kolesterol maupun kolesterol total nilai $p<0,000$ dengan arah hubungan positif.

Penelitian ini menggunakan ekstrak etanol $70 \%$ lidah buaya (Aloe vera $L$ ) dengan metode maserasi (Depkes, 2000). Hewan uji tikus putih jantan diadaptasi dan diberi pakan standar selama 1 minggu. Setelah adaptasi hewan uji dibagi kedalam 5 kelompok uji secara acak kemudian dilakukan pengambilan sampel darah lewat ekor untuk dicek kadar profil lipid (trigliserid, LDL-kolesterol dan kolesterol total) untuk pertama kali (data sebelum induksi). Semua tikus diberi makan dengan pakan tinggi kolesterol selama 2 minggu dan setelah itu dilakukan pengambilan sampel darah lagi untuk dicek kadar profil lipid yang kedua (setelah 
induksi). Prosedur berikutnya adalah pemberian perlakuan hewan uji sesuai kelompoknya yaitu kontrol negatif diberi aquades, kontrol positif diberi kolestiramin $0,2 \mathrm{mg} / 200 \mathrm{gBB}$, perlakuan ekstrak lidah buaya dosis I : $0,3 \mathrm{~g} / 20 \mathrm{gBB} / \mathrm{hari}$, perlakuan ekstrak lidah buaya dosis II : $0,6 \mathrm{~g} / 200 \mathrm{gBB} / \mathrm{hari}$, perlakuan ekstrak lidah buaya dosis III : $1,2 \mathrm{~g} / 200 \mathrm{gBB} /$ hari. Perlakuan hewan uji selama 14 hari, dan setelah itu dilakukan pengambilan sampel darah lagi untuk pengecekan kadar profil lipid yang ketiga (data setelah perlakuan). Data disajikan dalam tabel 1. Kadar profil lipid kedua dijadikan sebagai baseline perhitungan efek penurun profil lipid. Kadar profil lipid baseline setelah diuji dengan Lavene test dan Shapiro-Wilk didapatkan hasil normal dan homogen, sehingga penentuan efek penurun profil lipid digunakan data kadar profil lipid setelah perlakuan.

Berdasarkan tabel 1 hasil uji Paired T test data sebelum induksi dan sesudah induksi menunjukkan nilai $p<0,05$ yang artinya induksi untuk meningkatkan kadar profil lipid pada hewan uji dengan pakan hiperkolesterolemia berhasil. Pakan hiperkolesterolemia yang diberikan mengandung kolesterol dari kuning telur ayam sejumlah $1,5 \%$, kolesterol dari lemak kambing $10 \%$, dan kolesterol dari minyak kelapa $1 \%$ (Hardiningsih \& Nurhidayat, 2006).

Data profil lipid sesudah perlakuan (tabel 1) kemudian dilakukan uji One Way Anova dan didapatkan hasil $\mathrm{p}<0,05$ untuk masing-masing dari ketiga parameter profil lipid. Makna hasil uji ini menunjukkan paling tidak terdapat dua kelompok yang berbeda dari lima kelompok perlakuan. Untuk mengetahui kelompok mana saja yang berbeda, dilanjutkan uji pos hoc dengan menggunakan uji Least Significance Different $(L S D)$. Hasil uji LSD dapat dilihat pada tabel 2.

Dari tabel 2 hasil uji LSD perbandingan kelompok aquades dan kolestiramin nilai p < 0,05 , berarti terdapat perbedaan yang signifikan antara kontrol negatif (aquades) dengan kontrol positif (kolestiramin). Kolestiramin merupakan salah satu obat yang digunakan untuk menurunkan profil lipid. Obat ini termasuk dalam golongan bile acid sequestrant. Ada 3 jenis bile acid sequestrant yaitu kolestiramin, kolesevelam, dan kolestipol. Bile acid sequestrant bekerja dengan cara mengikat asam empedu (bukan kolesterol) di usus, akibatnya akan menghambat sirkulasi enterohepatik dari asam empedu. Zat ini juga meningkatkan perubahan kolesterol menjadi asam empedu di hati. Pemberian dosis tinggi kolestiramin (24 g) atau kolestipol $20 \mathrm{~g}$ dapat menurunkan kadar kolesterol LDL sebesar 1825\%. Sedangkan terhadap kolesterol HDL, bile acid sequestrant tidak berefek, namun kadar trigliserid dapat meningkat (PERKI, 2013).

Ada tidak nya efek penurun profil lipid dari ekstrak lidah buaya (Aloe vera $L$ ) dilihat dari angka p hasil uji LSD antara kelompok kontrol negatif (aquades) dengan kelompok perlakuan dengan pemberian ekstrak lidah buaya (Aloe vera $L$ ). Dari tabel 2 didapatkan perbandingan kelompok aquades dengan ekstrak Aloe vera $L$ $(0,3 \mathrm{~g} ; 0,6 \mathrm{~g}$; dan $1,2 \mathrm{~g})$ terhadap kadar trigliserid berbeda signifikan, artinya ekstrak Aloe vera $L$ $(0,3 \mathrm{~g} ; 0,6 \mathrm{~g} ;$ dan $1,2 \mathrm{~g})$ dapat menurunkan trigliserid. Sedangkan perbandingan kelompok ekstrak Aloe vera $L$ terhadap kadar LDL kolesterol dan kolesterol total yang berbeda bermakna hanya pada perlakuan dengan ekstrak Aloe vera $L 1,2 \mathrm{~g}$ saja.

Pembuatan ekstrak Aloe vera $L$ pada penelitian ini menggunakan etanol $70 \%$. Etanol menjadi pilihan utama sebagai pelarut dalam laboratorium. Alasan pemilihan ini karena etanol mempunyai kelarutan yang relatif tinggi. Etanol juga memiliki sifat inert sehingga tidak bereaksi dengan komponen lain (Susanti, et al., 2012). Etanol memiliki titik didih rendah, aman, tidak beracun dan tidak berbahaya. Etanol memiliki gugus -OH yang bersifat polar dan gugus $\mathrm{CH} 2 \mathrm{CH} 3$ yang bersifat non polar (Azis, et al., 2014). Sisi etanol yang bersifat polar akan menarik zat-zat aktif yang terdapat pada lidah buaya (Aloe vera $L$ ) yaitu glukomanan dan selulosa.

Akev et al., (2015) menjelaskan Aloe vera $L$ mengandung karbohidrat monosakarida, mukopolisakarida (glucomannans, acemannan, polymannose). Ahlawat dan Khatkar (2011) menjelaskan rantai polisakarida terpenting berupa glukosa dan mannosa, yang dikenal sebagai glucomannans $[\beta(1,4)$ - linked acetylated mannan]. Acemannan (glukomanan) memiliki komponen fungsi terpenting pada bagian gel (Bhuvana, et al., 2014). Polisakarida karbohidrat menempati $(55 \%)$ dari gel aloe vera kering, sedangkan gula $(17 \%)$, mineral $(16 \%)$, protein $(7 \%)$, lipid (4\%) dan fenolik (1\%) (Ahlawat dan Khatkar, 2011). Ekstrak etanol $70 \%$ lidah buaya (Aloe vera $L$ ) dapat menurunkan kadar trigliserid, LDL-kolesterol dan kolesterol total, karena lidah buaya memiliki zat aktif acemannan (glukomanan) dan selulosa (Munoz, et al., 2015).

Penelitian lain yang senada oleh Ugbaja et al., (2016) menjelaskan efek ekstrak gel Aloe vera $L$ peroral dapat menurunkan HDL tikus 
putih yang diinduksi streptozotocin. Penelitian oleh Sianipar dan Isnawati (2012) menggunakan jus lidah buaya dengan dosis $200 \mathrm{mg} / \mathrm{hari}$. Hasilnya jus lidah buaya dapat meningkatkan kadar HDL dan mampu menurunkan kadar kolesterol LDL secara signifikan. Penelitian oleh Wirya (2012) menggunakan ekstrak air lidah buaya dosis $1,5 \mathrm{ml}(1500 \mathrm{mg}) / 200 \mathrm{grBB} /$ hari pada tikus dislipidemia, hasilnya dapat memperbaiki profil lipid darah tikus. Hal ini diduga karena zat aktif glukomanan yang terkandung didalamnya. Aloe vera $L$ (lidah buaya) adalah fitofarmaka yang mengandung acemannan dan glucomannan yang aktivitasnya dapat menurunkan hiperkolesterolemia (Hanum, 2011).

Berdasar tabel 3 dapat dikatakan ketiga profil lipid yaitu trigliserid, LDL kolesterol dan kolesterol total memiliki hubungan searah dengan kekuatan sedang. Maknanya penurunan kadar trigliserid akan diikuti oleh penurunan LDL kolesterol dan kolesterol total. Dislipidemia disebabkan oleh terganggunya metabolisme lipid akibat interaksi faktor genetik dan faktor lingkungan. Terdapat bukti yang kuat hubungan antara kolesterol total, kolesterol LDL dengan kejadian penyakit kardiovaskular. Sedangkan peningkatan kadar trigliserid masih menjadi perdebatan untuk digunakan sebagai prediktor terhadap kejadian penyakit kardiovaskular. Peningkatan trigliserid sering disertai dengan penurunan kolesterol HDL dan peningkatan kadar kolesterol LDL. Berdasarkan hal ini diperkirakan pengaruh hipertrigliseridemia terhadap risiko kardiovaskular secara tidak langsung akibat rendahnya kolesterol HDL dan meningkatnya kolesterol LDL (PERKI, 2013). Hipertrigliserid merupakan komponen penting dari sindrom metabolik, dimana terjadi penurunan kadar HDL, resistensi insulin, hipertensi, dan obesitas sentral (abdomen). Kadar trigliserid yang tinggi juga berisiko menderita diabetes melitus tipe 2 (Katzung and bertram, 2012). Rekomendasi profil lipid yang diperiksa secara rutin adalah kolesterol total, kolesterol LDL, kolesterol HDL, dan trigliserid (PERKI, 2013).

\section{SIMPULAN}

Ekstrak etanol $70 \%$ Aloe vera $L$ dosis $1,2 \mathrm{~g} / 200 \mathrm{gBB} / \mathrm{hari}$ dapat menurunkan profil lipid berupa kadar trigliserid, LDL kolesterol dan kolesterol total dari tikus putih jantan model hiperkolesterolemia.

\section{DAFTAR PUSTAKA}

Ahlawat, K. S., dan Khatkar, B. S. P., 2011. Food Applications And Safety Of Aloe Vera Products: A Review. Journal of Food Science and Technology 48(5):525-533

Akev, N., Can, A., Sutlupınar, N., Candoken, E., Ozsoy, N., Ozden, T. Y., Yanardag, R., Uzen, E. 2012. Twenty years of research on Aloe vera. Journal of Faculty Pharmacy of Istanbul University. 45(2): 191-215

Azis, T., Febrizky, S. \& Mario, A. D., 2014. Pengaruh Jenis Pelarut Terhadap Persen Yield alkaloid Dari Daun Salam India (Murraya koenigii). Teknik Kimia. 20(2)

Bhuvana, K. B., Hema, N. G. \& Rajesh, P. T., 2014. Review On Aloe Vera. International Journal of Advanced Research. 3(2):677-691

Budijanto, D. 2015.2 Hipertensi. The Killer. http://www.pusdatin.kemkes.go.id/article/view/15080300001/hipertensi-the-silent-killer.html

Chandegara, V. K.; and Varshney, A. K. 2013. Aloe vera L. Processing and products : review. International Journal of Medicinal and Aromatic Plants. 3(4):492-506

Chatterjee, P., Chakraborty, B., And Nandy, S. 2013. Aloe Vera Plant : Review With Significant Pharmacological Activities. Mintage Journal Of Pharmaceutical \& Medical Sciences. 2(3):21-24.

Dariush, M. et al., 2015. Heart Disease and Stroke Statistics-2015. American Heart Association

Ditjen POM RI. 2000. Parameter Standar Umum Ekstrak Tumbuhan Obat. 1 ed. Jakarta: Departemen Kesehatan 
Hanum, D. F., 2011. Pengaruh Ekstrak Lidah Buaya Terhadap Kadar Malondialdehida Serum Darah Tikus Putih Hiperkolesterolemi. Skripsi.

Hardiningsih, R. \& Nurhidayat, N., 2006. Pengaruh Pemberian Pakan Hiperkolesterolemia terhadap Bobot. Biodiversitas. 7(2):127-130.

Kar, S. K., And Bera, T. K. 2018. Phytochemical Constituents Of Aloe Vera And Their Multifunctional Properties: A Comprehensive Review. International Journal of Pharmaceutical Sciences and Research. 9(4): 1416-1423.

Katzung and bertram., 2012. Basic \&clinical pharmacology.12th edition. New York:McGraw-Hill

Kemenkes RI 2017. Penyakit Jantung Penyebab Kematian Tertinggi, Kemenkes Ingatkan CERDIK. http://www.depkes.go.id/article/view/17073100005/penyakit-jantung-penyebab-kematiantertinggi-kemenkes-ingatkan-cerdik-.html

Kemenkes RI. 2018. Laporan Nasional Riskerdas 2018. Jakarta : Badan Penelitian dan Pengembangan Kesehatan.

Miroddi, M., Navarra, M., Calapai, F., Mancari, F., Giofre, S. V., Gangemi, S., Calapai, G. 2015. Review of Clinical Pharmacology of Aloe vera L. in the Treatment of Psoriasis. Phytotherapy Research Journal. 29(5):648-55.

Munoz, O., Leal, X. \& Cardemil, L., 2015. Extraction, Characterization and Properties of the Gel of Aloe Vera ( Aloe barbadensis Miller) Cultivated in Chile. Medicinal \& Aromatic Plants, $4(3)$.

Murray, C. J. L., Vos, T., Rafael, L. \& Naghavi, M., 2012. Disability-adjusted life years (DALYs) for 291 diseases and injuries in 21 regions, 1990-2010. Global Burden of Disease Study. 380:2197-2223.

Nelson, R. H. 2013. Hyperlipidemia as a Risk Factor for Cardiovascular Disease. https://www.ncbi.nlm.nih.gov/pmc/articles/PMC3572442/pdf/nihms422100.pdf

Nordestgaard BG. 2016. Triglyceride-Rich Lipoproteins and Atherosclerotic Cardiovascular Disease: New Insights From Epidemiology, Genetics, and Biology. Circulation Research. 118(4):547-63.

PERKI, 2013. Pedoman Tatalaksana Dislipidemia. Edisi Ke-1. Perhimpunan Dokter Spesialis Kardiovaskular Indonesia. Jakarta : Centra Communications.

Shattat, G. F. 2014. A Review Article on Hyperlipidemia: Types, Treatments and New Drug Targets. Biomedical \& Pharmacology Journal. 7(2) : 399-409.

Sianipar, Y., Isnawati, M. 2012. Pengaruh Pemberian Jus Lidah Buaya (Aloe Vera) Terhadap Kadar Kolesterol Low Density Lipoprotein (Ldl) Dan High Density Lipoprotein (Hdl). Journal of Nutrition College. 1(1) : 241-248

Susanti , A. D., Ardiana, D., P., G. G. \& G., Y. B., 2012. Polaritas Pelarut Sebagai Pertimbangan Dalam Pemilihan Pelarut Untuk Ekstraksi Minyak Bekatul Dari Bekatul Varietas Ketan (Oriza sativa Glatinosa). Simposium Nasional RAPI XI FT UMS

Ugbaja, R. N., Akinloye, D. I., Akamo, A. J., Ugwor, E. I., Iiesanmi, O. O., Tytler, O., Ogunbona, M., Ademuyiwa, O. 2016. Ameliorative Effects Of Aloe Vera Gel Extract On Circulatory And Tissue Lipid Profile Status In Streptozotocin-Induced Diabetic Rats. Bangladesh Journal of Medicinal Biochemistry. 9(1): 11-26 
Wadhera, R. K., Steen, D. L., Khan, I., Giugliano, R. P., Foody, J. M. 2016. A review of low-density lipoprotein cholesterol,treatment strategies, and its impact on cardiovascular disease morbidity and mortality. Review Articles. Journal of Clinical Lipidology. 10:472-489

Watts, G. F., Ooi, E. M., Chan, D. C. 2013. Demystifying the management of hypertriglyceridaemia. Nature Reviews Cardiology. 10(11):648-61.

Wirya, L. P. A. I. 2012. Pemberian Ekstrak Air Lidah Buaya (Aloe Vera L.) Memperbaiki Profil Lipid Darah Tikus Jantan Wistar Dengan Dislipidemia. Tesis 